\title{
The Depiction of True and Pure Love in Charlotte Bronte's Jane Eyre
}

\author{
Ali Albashir Mohammed Al-Haj ${ }^{1}$ \\ ${ }^{1}$ Jazan University, Jazan, Kingdom of Saudi Arabia \\ Correspondence: Ali Albashir Mohammed Al-Haj, Faculty of Arts \& Humanities, Department of English \& \\ literature, Jazan University, P. O. Box 114, Jazan, Kingdom of Saudi Arabia. E-mail: dr_abomathani@yahoo.com
}

\author{
Received: August 9, 2014 Accepted: October 4, 2014 Online Published: February 25, 2015 \\ doi:10.5539/ells.v5n1p97 URL: http://dx.doi.org/10.5539/ells.v5n1p97
}

\begin{abstract}
The current study aims at studying true and pure love in Jane Eyre. Charlotte never underestimates the power of love. In all her novels, it overcomes formidable barriers of wealth and rank, and endures through hopelessness and pain. In this story, the writer's idea about true and pure love expressed as an independent woman who needs to be loved by a companionate couple, with some kind of' equality between the ideal couples. Love in Charlotte's concept is pure, perfect and true and cannot be measured by jewels, riches, wealth, or position. Also, in this story the writer attempts a more ideal scheme of marriage which without love is lifeless, hence Jane rebuffs and rejects any proposal except that of her beloved lover, Mr. Rochester.
\end{abstract}

Keywords: true love, pure love, marriage, equality, ideal

\section{Introduction}

Jane tells her story as her own autobiography, but a part of it is also based on the life of her creator. The description of Lowood, and even of friends and teachers, correspond closely to Charlotte's own schooling at the Clergy Daughters' School (Spark, 1990, p. 78); and Jane's experience with the Ingrams, showing the kind of treatment a governess could expect, is based on Charlotte's personal knowledge. Reconstructions of various small events in her life are scattered through the book; the firing of Rochester's bed echoes an episode in Branwell's life; Bewick's British Birds was a favorite on the shelves at Haworth; the confinement of a mad woman in attic was a story Charlotte had heard at Stonegappe.

The greatness of a work of art is commensurate with the greatness of its inspiration and the adequacy of its means of communication. Now, the story of a woman in true love would be interesting but not necessarily great; the story of a woman's fight to express her own personality in love would be even more interesting but yet not necessarily great. Jane Eyre is great because it is these things and also something more. It is also the record of an intense spiritual experience, as powerful in its way as King Lear's ordeal of purgation, and it ends notably on a note of calm (Booth, 1998, p. 37). In Jane Eyre, young Jane discovers passion and fears it; and her early anger and sense of injustice are strongly and directly expressed.

When Jane Eyre opens, the reader learns that she has reached her goal: she is married to Rochester and has a son by him. The novel celebrates young Jane's ambition and determination in overcoming adversity and social prejudice. The novel has a distinctly Gothic atmosphere. Both the setting (a mansion with a mysterious attic) and Rochester's mad and violent wife create mystery and suspense. An element of the supernatural is also introduced through such devices as the telling of dreams, which foreshadow real events.

Young Jane's story, as well as being that of a romantic and Gothic heroine is also a progression in moral and spiritual terms. The situations in which she finds herself require that she should learn a Christian attitude to her own nature. Young Jane has also certain strong characteristics. She is passionate and imaginative-human sympathies and affections have a powerful hold on her. She thinks too much of the love of human beings. She longs for a wide experience of life.

True and pure love, indeed, is the one of main themes of Charlotte Bronte's Jane Eyre: for it was inevitably the central preoccupation of so passionate a temperament. Charlotte's power to describe it is, of course, conditioned by the nature of her genius. The novelist cannot dissect the workings of passion, nor can she illuminate its effect on character. What she can do is to convey its actual present throb. Moreover, this Charlotte does as it had never been done before in English fiction (Al-Haj, 2012, p. 25). 


\section{Charlotte Bronte's Contribution, Reputation and Quality of Writing}

\subsection{Charlotte Bronte's Life: Family Background}

Charlotte Bronte was born in April 1816 at Thornton in North Yorkshire, but when she was four her father became rector of Haworth, near Keighley, and the family moved into the parsonage which was to be Charlotte's home all her life. In 1821, when Charlotte was just five, her mother died and all five sisters were sent to live in an orphanage. Charlotte and her sisters were avid readers of Shakespeare, Milton, Byron, Scott, the Classics and the Bible. She and her sisters showed an early gift for writing, as a form of amusement they wrote miniature books about fantasy worlds of their own creation (Al-Haj, 2012, p. 19). In 1835, Charlotte left family home and took up a position as a teacher, but soon returned home suffering from homesickness. Charlotte worked for a time as governess in Brussels before returning and settling in Haworth. She began to move in literary circles. She travelled around England and wrote a novel set in Brussels, Villette (1853). In 1854, after much hesitation, she agreed to marry a local clergyman, but after just a few months of married life, she died due to complications associated with pregnancy.

\subsection{Charlotte Bronte's Contribution, Reputation and Writing Career}

Charlotte began writing as a child, and she was still writing in the year of her death. Her known spans twenty-six years, from her imitation of Blackwood's Magazine to her unfinished last novel, Emma. She usually wrote rapidly, feeling herself impelled to dash on. Sometimes she was overwhelmed by the need to write; at Roe Head in 1835 she noted, 'I am just going to write because I cannot help it' (Sulivan, 1996, p. 32). She welcomed this creative force, describing it (in the Preface to the 1850 edition of the novels) as 'something that, at times, strangely wills and works for itself' (Sulivan, 1996, p. 33). And she remarks in Shirley that' those who possess this imagination would not give it for gold' (Shirley, p. 89). For most of her writing life, she did nothing to discourage this urge, which often led her to disregard the stricter requirements of organization and plot, and made her obstinate about revision. None of her plots achieves the coherence of Emily's or Anne's. She is often tempted to include long irrelevant passages (Such as Lucy's visit to London in Villette), and she sometimes relies too heavily-especially in Jane Eyre, and Villette - on improbable coincidence. The plot of Shirley is astonishingly wayward for a writer of such skill. However, she learned from this novel, and as she became more distrustful of her 'inspiration' she spent more time on her plots. Villette is much more solidly constructed, and there are signs that in her last fragment, Emma, she intended to discipline her creative urges yet further (Sullivan, 1996, p. 37).

Jane Eyre is the first novel of a writer whose identity is concealed from the curious a pseudonym. It is not only the finest novel of Charlotte Bronte; it is perhaps the finest novel of our time. In no other modern novel does one encounter three characters so worthy of attention or which grip the imagination so powerfully as those of the little governess, the erring aristocrat and the despotic clergyman.

Charlotte Bronte's experience as governess left her embittered about the wealthy, leisured classes. It was not until late in her life that she encountered wealth combined with kindness. With the exception of Rochester and Shirley, all her chief characters, and all whom she admires, are people who have to earn their own living. The wealthy, such as the Ingrams (Jane Eyre or the Sympsons (Shirley)), do not command her respect, and indeed some are overdrawn to the point of caricature (Sullivan, 1996, p. 35).

Bronte's second masterpiece Shirley (1849) is a book about the predicament of women in love who suffer from unrequited love, women who have never, and never will be, loved. Charlotte never underestimates the power of love. In all her novels it overcomes formidable barriers of religion, wealth and rank, and endures through hopelessness and pain. The novel's two chief love-stories are entwined with other loves and marriages, past and present. Although it must be assumed that the marriage of Shirley and Louis, and Caroline and Robert, will be happy, happy marriage in Shirley are few and far between. Mrs. Pryor's marriage was disastrous, Helstone had made his wife wretched, Yorke married Hester only because he was jilted elsewhere, and Hester's views on marriage are briskly cynical. With the exception of Louis, the husbands and the men in love do not behave well; Robert proposes to Shirley for reasons of business, and the curate Malone sees no disgrace in pursuing marriage for wealth.

In all her writings career Charlotte shows herself sharply aware of class structure, in its relation both to rank and to wealth. Her own experience as a governess left her with a hostile contempt for the kind of prosperous, worldly families who had employed her (Sullivan, 1996, p. 70). 
The chief themes in Charlotte's Villette (1833) are all encompassed with Lucy's love story. Through her readers see a reconciling of the rational and the passionate, as she grows painfully from an observant, through repression and despair, to a loving, liberated woman.

In the Professor (1857), we have a description of Charlotte's ideal of womanhood. Mademoiselle Henri is an independent, warm, intelligent woman, who pays for her own lessons by lace-mending. She survives her dismissal, her aunt's death, and the loss of William with courage, before she finds security as a teacher. She has the spirit to stand up to the aggressive Hunsden, and insists that she retains her teaching post after marriage. She has little of Lucy's repressed emotional fervor, but they have much else in common. Taken in one dose, these accumulated virtues are difficult to swallow. But she has also the necessary qualities of independence, truth and honor, and 'the flame of natural passion burning under the eye of reasons' (Professor, p. 87). Henri is the first sketch of the typical Charlotte's heroine, in her typical posture-orphaned, little, plain, unnoticed, poor, but independent of spirit, firm of principle, and ambitious. Had Charlotte chosen to present the story through her eyes, the novel might have been less wooden. As it is, we see her only through Crimsworth's eyes, and in this way the main characteristic of her heroine is smothered- her strong, spirited egoism, which is revealed through thought and feeling as much as through deed.

Charlotte Bronte seems to have been happiest writing in the first person. Only one of her novels, Shirley, is objectively narrated, and she returned to the first person for Villette and the unfinished Emma. The method seems to have well suited to her strong, self-absorbed personality. Charlotte's aptitude for this form may be connected with her problems in creating characters. The "I" narrative enables her to identity with her heroines in such a way that she could make direct use of her own feelings and experience.

To conclude, Charlotte's personal reputation, helped to create a sympathetic atmosphere for the arrival of her new work. It was also the case that she had less to lose with her third novel than with her second, for the successor to a best-selling first book almost inevitably courts reactions of disappointment.

\section{The Portrayal of True and Pure Love e in Jane Eyre}

\subsection{The Main Theme of Jane Eyre}

The chief theme of Jane Eyre is revealed as a girl's growth to mature independence, and an equal partnership in love. Jane achieves her independence by her own spirited struggle through adversity, and she understands in the end that she is her own woman and can manage her own life. Although she chooses to devote herself to Rochester, she is not dependent on him and her choice is free. Not only is she free, but in her own eyes she is eventually his equal; 'equal- as we are!' she cries (Jane Eyre, p. 34), when they finally come together. The development of young Jane's love for Rochester, with all it reveals of the difficulties of a satisfactory relationship in love and marriage, lies at the core of the novel.

\subsection{The Story of Jane Eyre}

Jane Eyre begins her story as a ten-year old orphan in the house of her aunt, the authoritarian and unfeeling Mrs. Reed. Mrs. Reed accuses her of lying as a punishment sends her to Lowood Institution. After an unhappy adolescence there, she becomes a teacher and finds a job as governess to Adele, the illegitimate daughter of Mr. Rochester. Jane and Rochester fall in love, but on their wedding day she discovers that mysterious mad woman who lives in total seclusion in Rochester's house is really his wife. Despite his desperate pleas Jane runs away and is cared for by the Rivers family. She learns that she and Rivers are cousins and that she has inherited a considerable sum of money. When she is on the point of marrying Reverend St. John Rivers and emigrating to India, she telepathically hears Rochester's voice asking her to help him. She goes to Rochester Hall and finds it burnt down. Although Rochester has been blinded, she marries him and his sight is partially restored.

Jane's story reveals also, an abiding concern with religion, and the right relation to God. Although for a while God's image is obscured by that of Rochester, through all her sufferings Jane never doubts divine mercy, even when for a brief time she finds she cannot pray. When she leaves Rochester and faces death on the moors, she returns to God. Commending Rochester and her own soul to Him. Several different attitude to faith are exhibited and rejected; Mr. Brocklehurst's cruel hypocrisy, St. John's cold fanaticism, Helen's gentle acceptance, Mrs. Reed's refusal to forgive, and Eliza's rigid Catholicism, are all censured in various forms, fiercely, gently, or covertly. Jane believes it is right to struggle against adversity, but hatred and revenge are not permitted. Even as a child, momentarily triumphant after her outburst again Mrs. Reed, she soon regrets what she has done. (Sulivan, 1996, p. 89)

To conclude, it is also clear, from all we know of Charlotte's thoughts and feelings, that Jane's character is a close reflection of her own. Her painful conviction of her own lack of beauty, her views on love and marriage, 
her motherless state, her high intelligence, and her perseverance in adversity are all traits she shares with her heroine. But the fact that so much is drawn from Charlotte's life does not detract from the achievement of the book. Her creative intensity is such that all the material, real and invented, is equally fused into the stuff of her story.

\subsection{Jane Eyre and Idea of True and Pure Love}

Jane sees marriage as based on romantic love. Her passion for Rochester reveals itself trembling and flushing, and she is apprehensive about the strength of her own feelings. She rebuffs his advances, refutes to be treated to jewels and riches, and refuses to become his mistress. When they married she sees herself fulfilled as 'bone of his bone and flesh of his flesh' (Jane Eyre, p. 93). Like her, however, he is capable of learning from experience, and he grows in stature through the book. Again like Jane, he grows through suffering; which all his hopes of happiness, and then his physical strength as well, are removed from him, he struggles painfully through to a gentleness and calm. When Jane finds him at Ferndean, he has come bitterly to regret his attempted bigamy. He is mellowed and chastened, and has found a new strength in his submission to God's will. Although to today's reader her words seem so guarded, Charlotte never wrote so frankly again; critics accused her of coarseness and crudity, and the attack went deep (Sullivan, 1996, p. 55).

\subsection{Depiction of True and Pure Love in the Novel}

The world for Jane is to be Thornfield Hall, and her testing is to be in terms of that craving for love which she has always felt. Jane shows herself equal to the occasion. She can control her emotions even under Mr. Rochester's pretence of being in love with vivacious beautiful Ingram who is is determined to capture Mr. Rochester's wealth. Mr. Rochester encourages Ingram's hopes in order to arouse Jane's jealousy to, but he knows she does not love him. In spite of her pain, Jane finds it impossible to be jealous of her, because she is so contemptible. They are two totally contrasted women, one beautiful, the other plain; one rich, the other poor; one shallow, the other deep and complex.

Jane is horrified by Rivers' belief that love is not necessary in marriage, for to her love and marriage are indissoluble. To her Rivers' view of marriage is a kind of sacrilege, while to him it is a duty in the service of God. The ruthless force of his character is such that Jane begins to waver, and believe she ought to accept his proposal. His moral pressure places her in 'an iron shroud' (Jane Eyre, p. 98) and under' a freezing spell' (Jane Eyre, p.99), and his kiss becomes a seal on her fetters. He is merciless in his determination to take her to India as his wife, and stonily rebuffs her attempts at friendly reconciliation. Unscrupulously, he practices a kind of hypnotism on her, and she is almost on the point of surrender 'down the torrent of his will' (Jane Eyre, p.120) when she is saved by Rochester's cry. Pinion (1991, p. 46) has rightly pointed out that:

This extraordinary openness to feeling, this escape from the bondage of the trite, continues in the Rivers relationship, which is a structural parallel to the Rochester affairs: as in Rochester the old sex villain is seen in a new perspective, so in Rivers the clerical hero is radically refashioned; and Jane's almost accepting a would-be husband is given the aesthetic status of a regretful yielding to a seducer.

When Jane Eyre leaves Lowood School, she is but a novice in the world, in spite of her contact with the spiritual in the saintly Helen Burns and with the fleshly in Mrs. Reed. Indeed, to Jane the greatest thing in life is to be loved by a person. And we need not be surprised, for love of any kind has been so far denied to the child throughout her short life. Before such a novice, to whom the yearnings of the flesh and the spirit are at best indistinguishable, is placed the specious temptation in love, love imagined in its most stirring form, impetuous and violent- Mr. Rochester.

When Jane sets out for Thornfield next day, she arrives a day and a half later she finds it a blackened ruin. She discovers that it was burnt down by Bertha, who perished in the fire, while Rochester lost his sight and his left hand. He is now at his other house, Ferndean, thirty miles away, Jane finds him there, blind and helpless. He is at first unbelieving, then overwhelmed with joy. They arrange their marriage, and realize that each hearted the despairing cry of the other.

Writing ten years after the event, Jane finds their marriage perfect. Rochester has recovred his sight of one eye, and is able to see their first-born son. The last lines of the book are with St. John Rivers, who will soon die in his noble Christian service in India

Jane's struggle is a hard one; after the broken marriage at Thornfield, she is unwilling to leave her lover, Mr. Rochester, although she has seen the danger. Jane surmounts the obstacles and returns to Mr. Rochester and succeeds in obtaining true love and leads a happy life with him after a hard struggle. 


\section{Conclusion}

In an age when women were denied access to education and excluded from political debate, the publication of Jane Eyre was like a breath of fresh air. Her fiery independent temperament and fearless conviction were characteristics that went against the traditional portrayal of women. Charlotte Bronte, the most outstanding of the Bronte sisters, was not prepared to accept a world where women were second-class citizens. Jane Eyre is not only Charlotte Bronte's finest novel; it is perhaps the finest novel of our time.

Charlotte Bronte admired men who were strong in will. She expected in marriage to be 'well-ruled and ordered' by an exacting, rigid, law-giving and passionate husband. Through her protagonist Jane, the writer Bronte reflects that marriage without pure and true love is lifeless and motionless one, therefore, an ideal husband or wife selection is based on pure and pure love. Mr. Rochester and Jane marry, not in that first violent, physical anguish in which we saw them, but in a calmer, nobler mood, 'all passion spent'. Neither the flesh, nor the spirit, will tear Jane again, for from her double ordeal she has emerged unscathed, neither a profligate nor an ascetic, but a woman who has found an equable solution to the age-old problem which troubled others besides the Victorian but which troubled them intensely.

To conclude, that is Charlotte Bronte's Jane Eyre as it appears to us, a new contribution in English fiction which reflects aspects' of early Victorian social and economic phenomena. What Charlotte Bronte achieved in Jane Eyre was the cornerstone for a generation after generation.

\section{References}

Al-Haj, A. A. (2012). The Portrayal of Women in Charlotte Bronte's Shirley. Journal of Qena Faculty of Arts. South Valley University, Egypt.

Allott, M. (Ed.). (1989). The Brontes: The Critical Heritage. London: Rutledge and Kegan Paul.

Bentley, P. (1990). The Brontes and their World. London: Macmillan.

Booth, W. C. (1998). The Rhetoric of Fiction. University of Chicago Press: Chicago.

Bronte, C. (1990). The Professor. London: Macmillan.

Bronte, C. (1992). Jane Eyre. London: Macmillan.

Chang, H.-S. (1992). The Woman Question in Charlotte Bronte' Jane Eyre: The Interaction of Romanticism and Mid-nineteenth-century Victorian (Unpublished Master's Thesis). Lowa State University, Ames: Lowa.

Criak, W. A. (1999). The Life of Charlotte Bronte. London: Macmillan.

Cross, W. L. (1991). The Development of the English Novel. Englewood Cliffs: Salem Press.

Davies, S. (Ed.). (1991). The Brontes Sisters: Selected Poems. London: Macmillan.

Gao, H. Y. (2013). Reflection on Feminism in Jane Eyre. Theory and Practice in Language Studies, 3(6), 926-9331. http://dx.doi.org/10.4304/tpls.3.6.926-931

Gerin, W. (1994). Charlotte Bronte, the Evolution of Genius. London: Clarendon Press.

Lane, M. (1997). The Bronte Story. London: Heinemann.

Moglen, H. (1987). Charlotte Bronte. New York. Norton.

Pinion, F. B. (1991). Bronte's Companion. London: Macmillan.

Scott, P. (2001). Anne Bronte: A new Critical Assessment. London: Macmillan.

Smith, A. (Ed.). The Art of Charlotte Bronte. London: Macmillan.

Spark, M. (Ed.). (1990). The Bronte Letters. London: Macmillan.

Sullivan, S. (1996). Studying the Brontes. Hong Kong: York Press.

Winnifrith, T. (1990). The Brontes. London: Macmillan.

\section{Copyrights}

Copyright for this article is retained by the author(s), with first publication rights granted to the journal.

This is an open-access article distributed under the terms and conditions of the Creative Commons Attribution license (http://creativecommons.org/licenses/by/3.0/). 